\title{
Morphological Changes in Dental Surfaces Suggest Health Status and Alimentary Habits in the Subjects Belonging to the Copper Age in Sardinia Island (III Millennium BC)
}

\author{
Maria Elisabetta Murgia ${ }^{1 \mathbb{D}}$, Martina Salvatorina Murgia ${ }^{2}{ }^{(\mathbb{D}}$, Cinzia Casu ${ }^{3}$, Eleonora Casula $4(\mathbb{D}$, \\ Ornella Fonzo 5 , Giacomo Paglietti ${ }^{5}$ * (D) , Valentino Garau ${ }^{2}$ (D), Germano Orrù ${ }^{1,6}$ *(D) \\ 1 Private Paleopathology, Practice, Cagliari, Italy, memurgia92@gmail.com (M.E.M.); \\ 2 Department of Surgical Sciences, University of Cagliari, Cagliari, Italy, martina.murgia.s@gmail.com (M.M.S.); \\ garauva@yahoo.it (V.G.); orru@unica.it (G.O.); \\ 3 International PhD in Innovation Sciences and Technologies, University of Cagliari, Italy, ginzia.85@ hotmail.it (C.C.); \\ 4 Department of Life and Environmental Sciences, University of Cagliari, Cagliari, Italy, eleonoracasula@ hotmail.com \\ (E.C.); \\ 5 Archaeological Museum “Genna Maria”, Villanovaforru, South-Sardinia, Italy, ornellafonzo@virgilio.it (O.F.), \\ giacomo.paglietti@gmail.com (G.P.); \\ 6 Oral Biotechnology Laboratory, University of Cagliari, Cagliari, Italy, orru@ unica.it (G.O.); \\ * Correspondence: orru@ unica.it (G.O.), giacomo.paglietti@gmail.com (G.P.);
}

Received: 19.01.2020; Revised: 21.01.2021; Accepted: 24.01.2021; Pr

\begin{abstract}
The aim of this multidisciplinary study, which involved a team of archaeologists, odontologists, biologists, is to examine a set of dental health indicators, including caries, tooth wear, and enamel hypoplasia of a III millennium BC sample from the burial site of Scaba 'e Arriu (Siddi, South Sardinia), in order to evaluate the dental health status and the diet. Our purpose is to depict a timeline of dental health in Sardinia from prehistory to the present day, starting with a focus on a Copper Age population. Caries, dental wear, and enamel hypoplasia of 259 permanent teeth were evaluated. It was not possible to assign sex and age of each tooth because of the lack of bony support, lost due to taphonomy factors. 14,7\% of Scaba'e Arriu's samples were affected by carious lesions, with greater involvement of the posterior teeth (12,7\% against $1,9 \%$ of anterior ones). Interproximal caries was the most frequent. Dental wear affected $77,8 \%$ of the teeth, and its presence is preponderant over caries' rate. The high percentage of dental wear suggests a diet based on abrasive foods.

Further studies are necessary to delineate more accurately the modus vivendi, the nutrition, and, consequently, the health status of this sample.
\end{abstract}

Keywords: dental caries; copper age; dental wear; enamel hypoplasia; odontology; paleopathology; Sardinia.

(C) 2021 by the authors. This article is an open-access article distributed under the terms and conditions of the Creative Commons Attribution (CC BY) license (https://creativecommons.org/licenses/by/4.0/).

\section{Introduction}

Teeth are excellent indicators of an individual's health, diet, and lifestyle. For this reason, in recent years, the study of teeth has been spreading within the historicalarchaeological disciplines [1-6]. Teeth are often the only human material preserved unaltered in archaeological contexts since their structure is environmentally resistant and not prone to dramatic taphonomic changes. The examination of ancient teeth allows highlighting various pathological conditions [7] and diseases of variable etiology, including inflammatory odontogenic lesions [8] and benign $[9,10]$ or malignant $[11,12]$ neoplasms. Furthermore, since there were no dental therapies in the past, the assessment of pathologies of the orofacial district 
reflects the real condition of the studied population. The international scientific literature on dental paleopathology has until now focused on the reconstruction of oral health from osteoarchaeological samples starting from the presence of caries, inflammatory odontogenic lesions, periodontal diseases, and dental wear [13]. Other studies have applied imaging diagnostics more commonly used in health check [14] to investigate pathologies that cannot be otherwise found on a sample or morphometric features in dental evolution [15]. Another object of study is represented by past dietary habits, for which are analyzed common lesions on tooth's supporting tissues, enamel and dentine [16], and isotopic [17-20], molecular [21], and palaeobotanical data $[18,22]$. Also, researches have been performed on tooth's macro and micro-wear [23][24] and on the dental calculus [25]. It has, indeed, recently become an important source for ancient DNA studies with various purposes, i.e., depicting the evolution of the oral microbiota [26], getting more details on the human genome [27], investigating early eating habits [28], detecting and characterizing pathogenic microorganisms that have caused historical epidemics [29], reconstructing the demographic history of ancient populations [30].

Studies on dental findings in the Italian scientific literature are mostly part of broader research that focuses on whole skeletons or mummies [31]. And the same picture can be observed in Sardinia. Except for a few but significant research [32, 33], specific multidisciplinary and diachronic studies on archaeological teeth are currently unknown.

Our samples' peculiar feature is the great genetic uniformity based on autosomal and uniparental markers and on the increasing linkage disequilibrium (LD) [34]. Since Sardinia was included in the "Human Genome Diversity" project as a reference subject in Europe, our purpose is to analyze and carry out a comparative epidemiological analysis between widely chronologically distant Sardinian samples. Nevertheless, in this paper, we present a preliminary descriptive epidemiological analysis on Scaba 'e Arriu samples' dental health, waiting for other historical Sardinian samples to be compared, and with the will to provide data for further researches.

We developed our research using a multidisciplinary approach, in which the skills of the odontologist, the archaeologist, the paleopathologist, and the biologists converge.

\section{Materials and Methods}

Samples come from the collective burial of Scaba 'e Arriu (Siddi, South Sardinia province, (Figure 1.A), which architecture (Figure 1.B) is known as domu de janas (house of fairies) in Sardinian language, and date between Late Neolithic and Copper Age. The tomb was built in Late Neolithic period (4000-3300 BC) and reused in the later Copper Age by people of Filigosa-Abealzu's archaeological facies (3300-2700 BC, phase A) and Monte Claro's (27002200 BC, phase B) culture. Analyzed samples belong to phase A. Archaeological teeth were found devoid of their anatomical support because the burial was repurposed, resulting in bone deterioration. Moreover, no skeletons with anatomical connections were found. Therefore, it wasn't possible to assign sex nor a specific range of age to every sample. We recommend already published work by Usai et al., 2008 [35] for other archaeological details.

The samples are currently stored in the osteological laboratory of Villanovaforru's Archaeological Museum. For our study, we selected 259 permanent teeth classified, as shown in Table 1. 


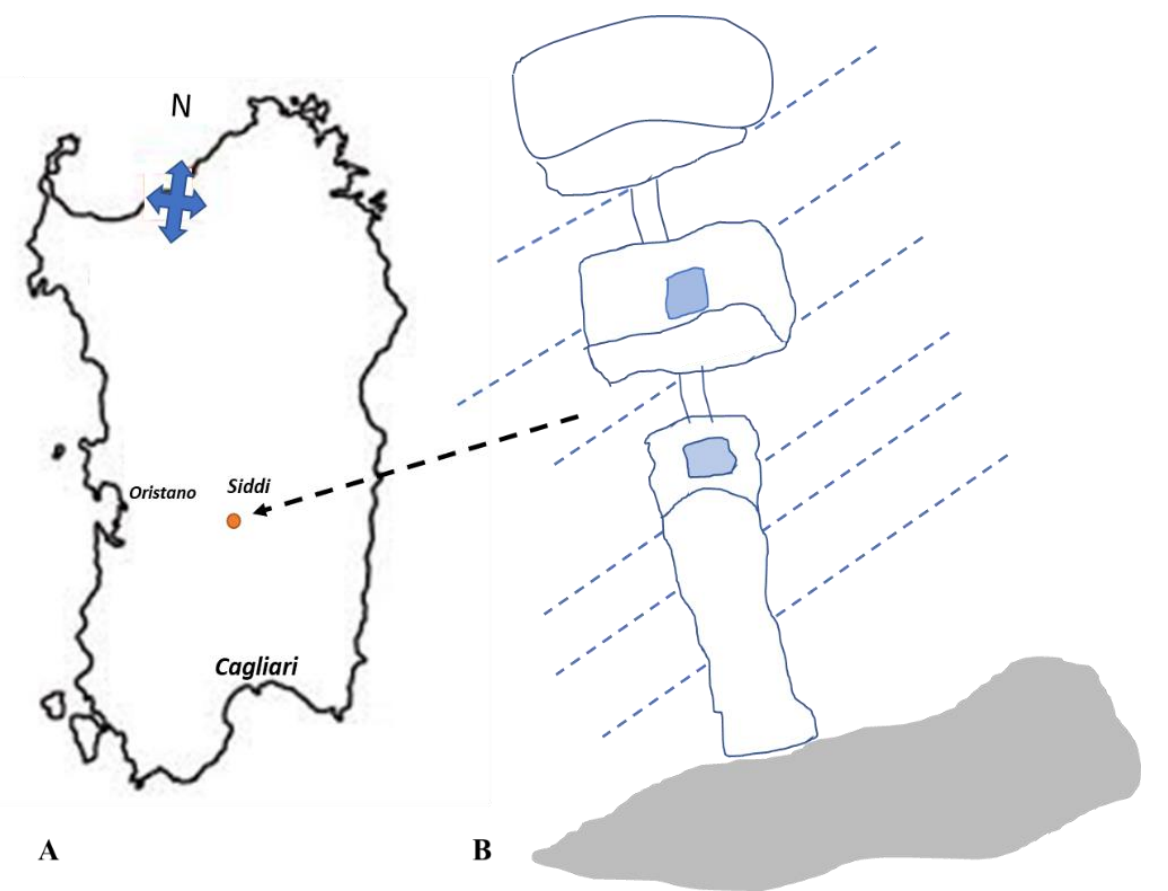

Figure 1. A) Geographical position and B) detail with axonometry of Scaba 'e Arriu's tomb (image of axonometry from [35]). Graphic editing by Carlo Murtas.

Table 1. Tooth type distribution of Scaba 'e Arriu's sample (phase A), based on lower and upper teeth.

\begin{tabular}{l|c|c} 
Tooth type & Lower arch & Upper arch \\
\hline Incisors & 20 & 20 \\
\hline Canines & 17 & 23 \\
\hline First premolars & 20 & 14 \\
\hline Second premolars & 20 & 15 \\
\hline First molars & 17 & 21 \\
\hline Second molars & 36 & 19 \\
\hline Third molars & 8 & 9
\end{tabular}

We considered teeth that were not altered by external factors, and they were examined using clinical procedures. Dental analyzes were performed with artificial lighting, using the following personal protective equipment to avoid any type of contamination: sterile latex gloves, surgical masks, protective glasses, and disposable gowns. Due to the lack of anatomical connections, the whole analysis was unfortunately run without any subdivision by sex and/or age.

Caries, dental wear, and enamel hypoplasia were evaluated. The presence of caries was assessed by naked eyes and subsequently using a dental explorer Hu-Friedy EX23/66. The carious lesion was considered as a clear loss of dental tissue or cavitation and recorded based on four scoring criteria: 1 superficial (caries in enamel), 2 moderate (caries in dentin and enamel undermined), 3 severe (pulp involvement), 4 destructive (death of pulp and possible periapical infection). Caries's severity was measured by using Hu-Friedy PCPUNC 15 periodontal probe.

Dental wear's severity was assessed by naked eyes and using Smith's qualitative scale [36] (developed from the study of hunter-gatherers and farmers populations), which assign a point scale to each tooth, from 0 (the stage of an unworn tooth) to 8 (the stage of a severely compromised tooth), based on the amount of exposed enamel and dentin. We divided the scale as follows: low severity (scores 1-2) from a polished crown or small facets to moderate cusp removal, moderate severity (scores 3-5) from full cusp removal, and lines of visible dentin to 
large areas of dentinal exposure, high severity (scores 6-8) from coalesced areas of dentinal exposure to severe or complete loss of the crown.

Enamel hypoplasia was recorded as a furrowed defect of enamel on the tooth's crown, which is the most common type. Nevertheless, the defect could also appear like a pit or a plane [37]. For each tooth, we calculated the number of hypoplastic grooves. To record the linear defects and their distances from the cementoenamel junction, we used a digital caliper and a magnifying glass 3-4x. However, this method requires to be strengthened with a scanning electron microscope analysis [38] and histological studies [39]. In this study, we only present preliminary data about global frequencies of affected teeth without focusing on each hypoplastic event's age range.

Statistical computations were run by using the Chi-Square test concerning the frequencies of caries and dental wear. The result was considered significant if the p-value was lower than 0.05. Tests were run on the open-access website Social Science Statistics (https://www.socscistatistics.com/).

\section{Results and Discussion}

$14,7 \%$ of Scaba 'e Arriu's sample was affected by carious lesions, especially in the posterior and inferior areas (Table 2), and the interproximal region (Figure 2) is the most evolved one (Table 3 ).

Table 2. Frequencies of carious teeth of the Scaba 'e Arriu's sample (phase A), based on inferior, superior, anterior, and posterior dental arches and total amount affected teeth. The number of observable teeth is 259 , while the number of affected teeth is 38 .

\begin{tabular}{l|c|c} 
Dental arches & $\mathbf{N}^{\circ}$ of involved teeth & Percentages of carious teeth \\
\hline Inferior & 23 & $8,9 \%$ \\
\hline Superior & 15 & $5,8 \%$ \\
\hline Anterior & 5 & $1,9 \%$ \\
\hline Posterior & 35 & $12,7 \%$ \\
\hline Total amount of carious teeth & 38 & $14,7 \%$
\end{tabular}

Table 3. Position of carious lesions of the Scaba 'e Arriu's sample (phase A), calculated on the number of observed lesions, which is 45 . The number of carious teeth doesn't equal the number of affected teeth, of which some have multiple lesions.

\begin{tabular}{l|c|c} 
Position of carious lesions & $\mathbf{N}^{\circ}$ of involved teeth & Percentages of carious lesions \\
\hline Occlusal & 7 & 15,6 \\
\hline Interproximal & 26 & 57,8 \\
\hline Lingual & 4 & 8,9 \\
\hline Buccal & 2 & 4,4 \\
\hline Neck & 4 & 8,9 \\
\hline Root & 1 & 2,2 \\
\hline Interproximal and incisal angle & 1 & 2,2
\end{tabular}

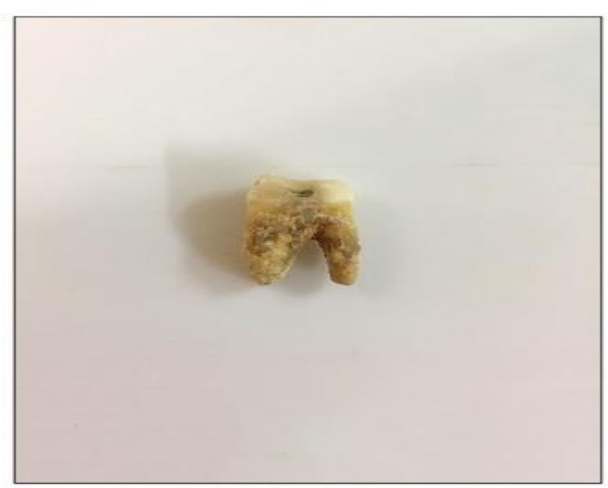

Figure 2. Interproximal caries on an upper second molar. 
The severity of the carious lesions is mostly moderate (Table 4).

Table 4. Severity of carious lesions of the Scaba 'e Arriu's sample (phase A), calculated on the number of observed lesions, which is 45 . The number of carious teeth doesn't equal the number of affected teeth, of which some have multiple lesions.

\begin{tabular}{l|c|c}
\hline Severity of carious lesions & $\mathbf{N}^{\circ}$ of carious lesions & Percentages of carious lesions \\
\hline Superficial & 15 & 33,3 \\
\hline Moderate & 23 & 51,1 \\
\hline Severe & 7 & 15,6 \\
\hline Destructive & 0 & 0 \\
\hline
\end{tabular}

Among 256 observable teeth, 201 (77,8\%) showed dental wear (Figure 3). All dental wear stages have been observed, but scores 6 and 7 have a low frequency, while stage 8 is absent (Table 5). Moderate severity is the most frequent class (39,9\% of total), but low severity almost equals it $(36,7 \%)$.

Table 5. Severity of dental wear of the Scaba 'e Arriu's sample (phase A), calculated on the number of observable teeth, which is 256 .

\begin{tabular}{l|c|c|c} 
Dental wear severity & Stage & $\mathbf{N}$ & $\mathbf{\%}$ \\
\hline Healthy teeth & $\mathbf{0}$ & 55 & 21,4 \\
\hline Low severity (from polished crown or & $\mathbf{1}$ & 42 & 16,4 \\
\cline { 2 - 4 } small facets to moderate cusp removal) & $\mathbf{2}$ & 52 & 20,3 \\
\hline Moderate severity (from full cusp removal & $\mathbf{3}$ & 45 & 17,6 \\
\cline { 2 - 4 } $\begin{array}{l}\text { and lines of visible dentin to large areas of } \\
\text { dentinal exposure) }\end{array}$ & $\mathbf{4}$ & 26 & 10,2 \\
\cline { 2 - 4 } $\begin{array}{l}\text { High severity (from coalesced areas of } \\
\text { dentinal exposure to severe or complete loss } \\
\text { of crown) }\end{array}$ & $\mathbf{5}$ & 31 & 12,1 \\
\cline { 2 - 4 } & $\mathbf{7}$ & 3 & 0,8 \\
\hline
\end{tabular}
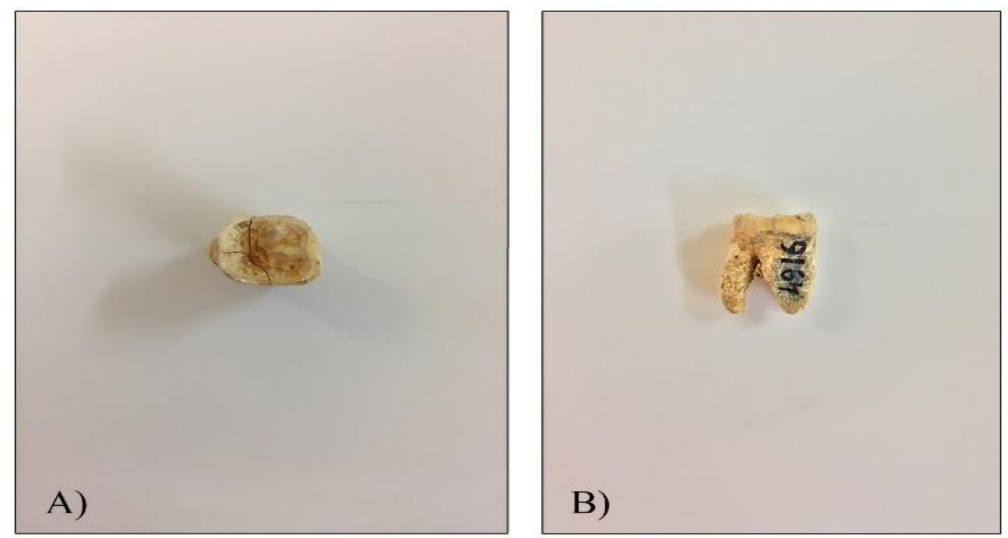

Figure 3. Occlusal dental wear with moderate severity (cusp removal and large dentinal exposure areas) on a second upper molar. A) occlusal view, B) interproximal view.

Table 6 compares the rates of caries and wear among anterior/posterior and maxillary/mandibular teeth: in each comparison, the dental wear score is always preponderant over caries' one.

Table 6. Comparison among values of dental wear and caries of the Scaba 'e Arriu's sample (phase A).

\begin{tabular}{l|c|c|c|c|c|c|c|c} 
& \multicolumn{2}{|c|}{ Inferior teeth } & \multicolumn{2}{c|}{ Superior teeth } & \multicolumn{2}{c|}{ Anterior teeth } & \multicolumn{2}{c}{ Posterior teeth } \\
\hline & $\mathbf{N}^{\circ}$ & $\mathbf{\%}$ & $\mathbf{N}^{\circ}$ & $\mathbf{\%}$ & $\mathbf{N}^{\circ}$ & $\mathbf{\%}$ & $\mathbf{N}^{\circ}$ & \% \\
\hline Dental wear & 110 & 42,9 & 88 & 34,3 & 59 & 23 & 139 & 54,3 \\
\hline Dental caries & 23 & 8,9 & 15 & 5,7 & 5 & 1,93 & 33 & 12,7
\end{tabular}

$11,7 \%$ of teeth were affected by enamel hypoplasia (Table 7). The furrowed type was visible only. 
Table 7. Global frequencies of enamel hypoplasia of the Scaba 'e Arriu's sample (phase A). We only were able to report the furrowed or linear type.

\begin{tabular}{c|c|c|c}
$\begin{array}{c}\mathbf{N}^{\circ} \text { of hypoplastic } \\
\text { events }\end{array}$ & $\begin{array}{c}\mathbf{N}^{\circ} \text { of observable } \\
\text { teeth }\end{array}$ & $\begin{array}{c}\mathbf{N}^{\circ} \text { of affected } \\
\text { teeth }\end{array}$ & $\begin{array}{c}\text { Percentage of } \\
\text { affected teeth }\end{array}$ \\
\hline 51 & 249 & 30 & $12 \%$
\end{tabular}

Dental elements are more affected by wear than caries; thus, it is possible that Scaba 'e Arriu's samples were involved in a more traumatic process, other than a cariogenic one, due to food texture was probably tougher and contained coarse particles, making chewing heavy. Therefore, dental wear is probably connected not only with the chewing but also with the food's consistency, while caries are mostly related to the food's quality. It should be stressed that "wear" is an umbrella term for several phenomena, which includes several types of lesions, and that we weren't able to perform a microscopic observation of the patterns, which would have been a more accurate analysis [40]. Tooth wear has a multifactorial etiology, and it usually occurs with two or more combined mechanisms. It includes attrition (caused by the contact between occlusal or incisal surfaces), abrasion (caused by the contact between tooth's surface and a foreign object), and erosion (a caused by acid and chelating agents, which promote the loss of hard tissue and accelerate attrition or abrasion processes), but more specific mechanisms, patterns, and causes can be found [41]. Tooth wear could be due to extra-chewing factors such as bruxism, GERD (gastroesophageal reflux disease), eating disorders, the use of teeth as tools, etc. [42]. In the past, there was probably more abrasion and/or attrition than erosion. The latter seems to be specific to the modern age: recent studies recorded a high presence of erosive wear, especially in children and adolescents, and that occurrence of erosion is increasing. The reason could be found in acid-rich foods and drinks, which were less consumed in the past. Erosive wear is also occupationally related: airborne acid reached the teeth of industrial workers. Indeed, a clear change of oral health direction has occurred between past and present, the latter being an actual major public health problem [43].

Mandibular teeth appear to be more markedly affected by caries than the maxillary ones. Therefore, this may be due to a little adequate cleaning system, while in the superior dental arch, we have the washing action of the parotid gland, which carries out an anticariogenic function through the production of saliva. Moreover, the food tends to stand on the mandibular area because of gravity: without a correct cleaning system, this only promotes caries' formation.

The prevalence of interproximal caries may be due to lack of a "dental floss" and, consequently, to the accumulation of food residues and a bacterial film's development. Moreover, the abrasive function of food may have avoided the occurrence of caries on occlusal surfaces, slowing and eventually halting the cariogenic demineralization process.

The main problem of our study is that we haven't a full picture of our sample yet: we couldn't assess the age and sex of every sample, so we don't know how much these factors may or may not have influenced the development of the dental pattern that we observed.

An interesting comparison can be made between Scaba 'e Arriu's samples with the ones from another Sardinian burial site, called Mont'e Prama, which dates to the Iron Age (1100-800 B.C.) [33]. In the latter, the severity of dental wear was not high, even in the older individuals, and the isotopic analysis showed that the population has fed on cooked and softened foods, poor in-ground cereals, and rich in animal proteins. Also, 4,8\% of the teeth' total showed caries, which was generally small and occlusal: that is, a completely different and opposite pattern compared to our samples. Thanks to the isotopic investigations carried out on 
Scaba 'e Arriu's bone collagen [44], it was found that the diet was mainly based on the consumption of vegetable products such as cereals and legumes and, scarcely, of animal proteins (swine). These data, combined with inadequate oral hygiene, justify the percentage of carious lesions $(14,7 \%)$, which seems to be high for the prehistoric world [13, 33].

The greater presence of tooth wear in the Scaba 'e Arriu's sample is hypothetically due to a diet rich in more abrasive foods, but also the grinding process of cereals using millstones, which release abrasive residues in food as confirmed by other bio-archaeological studies [45].

Finally, enamel hypoplasia is a condition frequently found in ancient populations [46], as they were more exposed to nutritional (such as malnutrition, avitaminosis) and infectious (prolonged infections, intestinal parasitosis) stresses. Scaba 'e Arriu's hypoplasia frequency is not high compared to those of other ancient populations. Therefore, it's hypothesized a diet rich in vitamins.

The tomb of Scaba 'e Arriu is quite interesting because two communities from two different times choose to set up a home for their dead in the same place. Indeed, it would be interesting to compare the oral status of phases $\mathrm{A}$ and $\mathrm{B}$, with the aim to find out any differences among caries', dental wear's, and enamel hypoplasia's rates. The aforementioned isotopic study on bone collagen was run on bones from each phase. It showed an increase in animal protein consumption from phase A to phase B. That comparison would be important not only in the archaeological field, concerning any cultural or sociological reason behind nutritional choices but also in the biological and pathological branches that focus on nutritional mechanisms and consequences.

\section{Conclusions}

The oral health pattern study showed that Scaba 'e Arriu's samples had a high percentage of dental wear, that's preponderant over caries' one. This could indicate both a diet based on abrasive foods and production tools, such as an ancient millstone, which releases mineral residues on food during the grinding process. Indeed, nutrition may have played a decisive role in outlining this picture. More detailed research on dental wear's patterns could tell us more about food choices and food processing tools.

In a previous study [47], we compared our Copper Age cohort with present-day teeth, showing a dramatic difference between the two samples: modern samples showed a significantly higher incidence of caries and a lower one of dental wear, each one related to a diet rich in processed carbohydrates and soft food. Furthermore, the absence of linear enamel hypoplasia in present-day teeth highlights the absence of nutritional or infectious stress during the period of dental ontogenesis. Nevertheless, these are preliminary studies: for instance, it would be interesting to compare levels of the Streptococcus mutans, which is an important etiologic agent in dental caries, among samples of Scaba'e Arriu's phases A and B, of Mont'e Prama, and the modern age, in order to verify the decreasing tendency of caries' frequency observed from our studies. Further multidisciplinary researches, which should especially converge archaeological, microscopic, and biomolecular elements, will give us more specific data. 


\section{Funding}

This work was supported by grants from "Contributo premiale 2013, Bando di Rilevanza Nazionale, L.R. n. 7/2007" from the University of Cagliari and the Regione Autonoma della Sardegna and by Fondazione di Sardegna" year 2018.

\section{Acknowledgments}

We thank Soprintendenza per i beni archeologici per le Province di Cagliari e Oristano for permission to conduct the research.

\section{Conflicts of Interest}

The authors declare no conflict of interest.

\section{References}

1. Przystańska, A.; Lorkiewicz-Muszyńska, D.; Abreu-Głowacka, M.; Glapiński, M.; Sroka, A.; Rewekant, A.; Hyrchała, A.; Bartecki, B.; Żaba, C.; Kulczyk, T. Analysis of human dentition from Early Bronze Age: 4000year-old puzzle. Odontol. 2017, 105, 13-22, https://doi.org/10.1007/s10266-015-0220-7.

2. Giuffra, V.; Milanese, M.; Minozzi, S. Dental health in adults and subadults from the 16th-century plague cemetery of Alghero (Sardinia, Italy). Archives of Oral Biology 2020, 120, https://doi.org/10.1016/j.archoralbio.2020.104928.

3. Chanamé-Marín, A.; Reátegui-Navarro, M.; Arbildo-Vega, H. Prevalence of dental paleopathology in a peruvian pre-hispanic population. J. Oral. Res. 2019, 8, 147-151, https://doi.org/10.17126/jor.v0i0.774.

4. Gagnon, C.M. Exploring oral paleopathology in the Central Andes: A review. International Journal of Paleopathology 2020, 29, 24-34, https://doi.org/10.1016/j.ijpp.2019.10.003.

5. Suby, J.A. Paleopathological research in southern Patagonia: An approach to understanding stress and disease in hunter-gatherer populations. Lat. Am. Antiq. 2020, 31, 392-408, https://doi.org/10.1017/laq.2020.5.

6. Petersone-Gordina, E.; Roberts, C.; Millard, A.R.; Montgomery, J.; Gerhards, G. Dental disease and dietary isotopes of individuals from St Gertrude Church cemetery, Riga, Latvia. PLOS ONE 2018, 13, https://doi.org/10.1371/journal.pone.0191757.

7. Rajić Šikanjić P.; Premužić Z.; Meštrović S. Hide and seek: Impacted maxillary and mandibular canines from the Roman period Croatia. Int. J. Paleopathol. 2019, 24, 89-93, https://doi.org/10.1016/j.ijpp.2018.10.004.

8. Assis, S.; Casimiro, S.; Alves Cardoso, F. Is it a cystic or a cyst-like condition? Discussing the etiology of an unusual large mandibular lesion in a Roman skeleton from Quinta da Torrinha/Quinta de Santo António (Almada, Portugal). Int. J. Paleopathol. 2018, 22, 149-157, https://doi.org/10.1016/j.ijpp.2018.01.006.

9. Castro, M.; Goycoolea, M.; Galvez, M.; Silva, V.; Montoya, C.; Fuentes, J. Mastoid osteoma in a prehispanic cranium (1390 A.D.) from Northern Chile. International Journal of Paleopathology 2019, 24, 141-143, https://doi.org/10.1016/j.ijpp.2018.10.006.

10. Craig, E.; Craig, G. The Diagnosis and Context of a Facial Deformity from an Anglo-Saxon Cemetery at Spofforth, North Yorkshire. Int. J. Osteoarchaeol. 2013, 23, 631-639, https://doi.org/10.1002/oa.1288.

11. Molnár, E.; Schultz, M.; Schmidt-Schultz, T.H.; Marcsik, A.; Buczkó, K.; Zádori, P.; Biró, G.; Bernert, Z.; Baumhoer, D.; Hajdu, T. Rare Case of an Ancient Craniofacial Osteosarcoma with Probable Surgical Intervention. Pathology \& Oncology Research 2017, 23, 583-587, https://doi.org/10.1007/s12253-0160153-7.

12. Inchingolo, F.; Santacroce, L.; Ballini, A.; Topi, S.; Dipalma, G.; Haxhirexha, K.; Bottalico, L.; Charitos, I.A. Oral Cancer: A Historical Review. International Journal of Environmental Research and Public Health 2020, 17, https://doi.org/10.3390/ijerph17093168.

13. Eshed, V.; Gopher, A.; Hershkovitz, I. Tooth wear and dental pathology at the advent of agriculture: New evidence from the Levant. American Journal of Physical Anthropology 2006, 130, 145-159, https://doi.org/10.1002/ajpa.20362.

14. Gerloni, A.; Cavalli, F.; Costantinides, F.; Costantinides, F.; Bonetti, S.; Paganelli, C. Dental status of three Egyptian mummies: radiological investigation by multislice computerized tomography. Oral Surgery, Oral Medicine, Oral Pathology, Oral Radiology and Endodontics 2009, 107, e58-e64, https://doi.org/10.1016/j.tripleo.2009.02.031.

15. Zanolli, C.; Martinón-Torres, M.; Bernardini, F.; Boschian, G.; Coppa, A.; Dreossi, D.; Mancini, L.; Martínez de Pinillos, M.; Martín-Francés, L.; Bermúdez de Castro, J.M.; Tozzi, C.; Tuniz, C.; Macchiarelli, 
R. The Middle Pleistocene (MIS 12) human dental remains from Fontana Ranuccio (Latium) and Visogliano (Friuli-Venezia Giulia), Italy. A comparative high resolution endostructural assessment. PLOS ONE 2018, 13,https://doi.org/10.1371/journal.pone.0189773.

16. Novak, M. Dental health and diet in early medieval Ireland. Archives of Oral Biology 2015, 60, 1299-1309, https://doi.org/10.1016/j.archoralbio.2015.06.004.

17. Li, Q.; Nava, A.; Reynard, L.M.; Thirlwall, M.; Bondioli, L.; Müller, W. Spatially-Resolved Ca Isotopic and Trace Element Variations in Human Deciduous Teeth Record Diet and Physiological Change. Environmental Archaeology 2020, 6, 1-10, https://doi.org/10.1080/14614103.2020.1758988.

18. Bliujienè, A.; Skipitytė, R.; Garbaras, A.; Miliauskienė, Ž.; Šapolaitė, J.; Ežerinskis, Ž.; Čeponkus, J.; Masiulienè, I.; Simčenka, E.; Minkevičius, K.; Piličiauskienè, G. The first data on the human diet in Late Roman and Early Migration period western Lithuania: Evidence from stable isotope, archaebotanical and zooarchaeological analyses. Journal of Archaeological Science: Reports 2020, 33, https://doi.org/10.1016/j.jasrep.2020.102545.

19. Dąbrowski, P.; Kulus, M.; Grzelak, J.; Radzikowska, M.; Oziembłowski, M.; Domagała, Z.; Krajcarz, M.T. Assessing weaning stress - Relations between enamel hypoplasia, $\delta 180$ and $\delta 13 \mathrm{C}$ values in human teeth obtained from early modern cemeteries in Wroclaw, Poland. Annals of Anatomy - Anatomischer Anzeiger 2020, 232, https://doi.org/10.1016/j.aanat.2020.151546.

20. Yi, B.; Liu, X.; Yuan, H.; Zhou, Z.; Chen, J.; Wang, T.; Wang, Y.; Hu, Y.; Fuller, B.T. Dentin isotopic reconstruction of individual life histories reveals millet consumption during weaning and childhood at the Late Neolithic (4500 bp) Gaoshan site in southwestern China. International Journal of Osteoarchaeology 2018, 28, 636-644, https://doi.org/10.1002/oa.2676.

21. Sawafuji, R.; Saso, A.; Suda, W.; Hattori, M.; Ueda, S. Ancient DNA analysis of food remains in human dental calculus from the Edo period, Japan. PLOS ONE 2020, 15, https://doi.org/10.1371/journal.pone.0226654.

22. Power, R.C.; Salazar-García, D.C.; Rubini, M.; Darlas, A.; Harvati, K.; Walker, M.; Hublin, J.-J.; Henry, A.G. Dental calculus indicates widespread plant use within the stable Neanderthal dietary niche. Journal of Human Evolution 2018, 119, 27-41, https://doi.org/10.1016/j.jhevol.2018.02.009.

23. Ungar, P.S. Inference of Diets of Early Hominins from Primate Molar Form and Microwear. J. Dent. Res. 2019, 98, 398-405, https://doi.org/10.1177/0022034518822981.

24. Fiorenza, L.; Benazzi, S.; Kullmer, O.; Zampirolo, G.; Mazurier, A.; Zanolli, C.; Macchiarelli, R. Dental macrowear and cortical bone distribution of the Neanderthal mandible from Regourdou (Dordogne, Southwestern France). Journal of Human Evolution 2019, 132, 174-188, https://doi.org/10.1016/j.jhevol.2019.05.005.

25. Weyrich, L.S.; Duchene, S.; Soubrier, J.; Arriola, L.; Llamas, B.; Breen, J.; Morris, A.G.; Alt, K.W.; Caramelli, D.; Dresely, V.; Farrell, M.; Farrer, A.G.; Francken, M.; Gully, N.; Haak, W.; Hardy, K.; Harvati, K.; Held, P.; Holmes, E.C.; Kaidonis, J.; Lalueza-Fox, C.; de la Rasilla, M.; Rosas, A.; Semal, P.; Soltysiak, A.; Townsend, G.; Usai, D.; Wahl, J.; Huson, D.H.; Dobney, K.; Cooper, A. Neanderthal behaviour, diet, and disease inferred from ancient DNA in dental calculus. Nature 2017, 544, 357-361, https://doi.org/10.1038/nature21674.

26. Velsko, I.M.; Fellows Yates, J.A.; Aron, F.; Hagan, R.W.; Frantz, L.A.F.; Loe, L.; Martinez, J.B.R.; Chaves, E.; Gosden, C.; Larson, G.; Warinner, C. Microbial differences between dental plaque and historic dental calculus are related to oral biofilm maturation stage. Microbiome 2019, 7, https://doi.org/10.1186/s40168019-0717-3.

27. Ziesemer, K.A.; Ramos-Madrigal, J.; Mann, A.E.; Brandt, B.W.; Sankaranarayanan, K.; Ozga, A.T.; Hoogland, M.; Hofman, C.A.; Salazar-García, D.C.; Frohlich, B.; Milner, G.R.; Stone, A.C.; Aldenderfer, M.; Lewis Jr, C.M.; Hofman, C.L.; Warinner, C.; Schroeder, H. The efficacy of whole human genome capture on ancient dental calculus and dentin. American Journal of Physical Anthropology 2019, 168, 496509, https://doi.org/10.1002/ajpa.23763.

28. Gismondi, A.; Baldoni, M.; Gnes, M.; Scorrano, G.; D’Agostino, A.; Di Marco, G.; Calabria, G.; Petrucci, M.; Müldner, G.; Von Tersch, M.; Nardi, A.; Enei, F.; Canini, A.; Rickards, O.; Alexander, M.; MartínezLabarga, C. A multidisciplinary approach for investigating dietary and medicinal habits of the Medieval population of Santa Severa (7th-15th centuries, Rome, Italy). PLOS ONE 2020, 15, https://doi.org/10.1371/journal.pone.0227433.

29. Fotakis, A.K.; Denham, S.D.; Mackie, M.; Orbegozo, M.I.; Mylopotamitaki, D.; Gopalakrishnan, S.; Sicheritz-Pontén, T.; Olsen, J.V.; Cappellini, E.; Zhang, G.; Christophersen, A.; Gilbert, M.T.P.; Vågene, Å.J. Multi-omic detection of Mycobacterium leprae in archaeological human dental calculus. Philosophical Transactions of the Royal Society B: Biological Sciences 2020, 375, https://doi.org/10.1098/rstb.2019.0584.

30. Eisenhofer, R.; Kanzawa-Kiriyama, H.; Shinoda, K.-i.; Weyrich, L.S. Investigating the demographic history of Japan using ancient oral microbiota. Philosophical Transactions of the Royal Society B: Biological Sciences 2020, 375, https://doi.org/10.1098/rstb.2019.0578.

31. Becker, M.; Capasso, L. I Fuggiaschi di Ercolano: paleobiologia delle vittime dell'eruzione Vesuviana del 79 D.C. L'Erma di Bretschneider, Rome, Italy, 2001. 
32. Casula, E.; Orrù, G.; Contu, M.; Demontis, C.; Serreli, G. Periodontal microbiota of Sardinian children: Comparing 200-year-old samples to present-day ones. Journal of Pediatric and Neonatal Individualized Medicine 2017, 6, https://doi.org/10.7363/060123.

33. Angelini I.; Artioli G. Gli inumati nella necropoli di Mont'e Prama. In: Le sculture di Mont'e Prama Contesto, scavi e materiali. Gangemi Editore Spa, Rome, Italy, 2014; pp. 175-200.

34. Chiang, C.W.K.; Marcus, J.H.; Sidore, C.; Biddanda, A.; Al-Asadi, H.; Zoledziewska, M.; Pitzalis, M.; Busonero, F.; Maschio, A.; Pistis, G.; Steri, M.; Angius, A.; Lohmueller, K.E.; Abecasis, G.R.; Schlessinger, D.; Cucca, F.; Novembre, J. Genomic history of the Sardinian population. Nature Genetics 2018, 50, 14261434, https://doi.org/10.1038/s41588-018-0215-8.

35. Usai E.; Fonzo O.; Mascia F. L'ipogeo di Scaba 'e Arriu di Siddi: i rituali funerari e cultuali e le offerte animali. In Proceedings of the XLIII Riunione Scientifica dell'Istituto Italiano di Preistoria e Protostoria: l'Età del Rame in Italia, Bologna, Italy, 26-29 November 2008, 2011; pp. 363-371.

36. Smith, B.H. Patterns of molar wear in hunter-gatherers and agriculturalists. American Journal of Physical Anthropology 1984, 63, 39-56, https://doi.org/10.1002/ajpa.1330630107.

37. Hillson, S.; Bond, S. Relationship of enamel hypoplasia to the pattern of tooth crown growth: A discussion. American Journal of Physical Anthropology 1997, 104, 89-103, https://doi.org/10.1002/(SICI)10968644(199709)104:1<89::AID-AJPA6>3.0.CO;2-8.

38. Hassett, B.R. Evaluating sources of variation in the identification of linear hypoplastic defects of enamel: a new quantified method. Journal of Archaeological Science 2012, 39, 560-565, https://doi.org/10.1016/j.jas.2011.10.017.

39. Ritzman, T.B.; Baker, B.J.; Schwartz, G.T. A fine line: A comparison of methods for estimating ages of linear enamel hypoplasia formation. American Journal of Physical Anthropology 2008, 135, 348-361, https://doi.org/10.1002/ajpa.20750.

40. Levrini, L.; Di Benedetto, G.; Raspanti, M. Dental Wear: A Scanning Electron Microscope Study. BioMed Research International 2014, 2014, https://doi.org/10.1155/2014/340425.

41. d'Incau, E.; Couture, C.; Maureille, B. Human tooth wear in the past and the present: Tribological mechanisms, scoring systems, dental and skeletal compensations. Archives of Oral Biology 2012, 57, 214229, https://doi.org/10.1016/j.archoralbio.2011.08.021.

42. Kaidonis, J.A.; Ranjitkar, S.; Lekkas, D.; Townsend, G.C. An Anthropological Perspective: Another Dimension to Modern Dental Wear Concepts. International Journal of Dentistry 2012, 2012, https://doi.org/10.1155/2012/741405.

43. James, S.L.; Abate, D.; Abate, K.H.; Abay, S.M.; Abbafati, C.; Abbasi, N.; Abbastabar, H.; Abd-Allah, F.; Abdela, J.; Abdelalim, A.; Abdollahpour, I.; Abdulkader, R.S.; Abebe, Z.; Abera, S.F.; Abil, O.Z.; Abraha, H.N.; Abu-Raddad, L.J.; Abu-Rmeileh, N.M.E.; Accrombessi, M.M.K.; Acharya, D.; Acharya, P.; Ackerman, I.N.; Adamu, A.A.; Adebayo, O.M.; Adekanmbi, V.; Adetokunboh, O.O.; Adib, M.G.; Adsuar, J.C.; Afanvi, K.A.; Afarideh, M.; Afshin, A.; Agarwal, G.; Agesa, K.M.; Aggarwal, R.; Aghayan, S.A.; Agrawal, S.; Ahmadi, A.; Ahmadi, M.; Ahmadieh, H.; Ahmed, M.B.; Aichour, A.N.; Aichour, I.; Aichour, M.T.E.; Akinyemiju, T.; Akseer, N.; Al-Aly, Z.; Al-Eyadhy, A.; Al-Mekhlafi, H.M.; Al-Raddadi, R.M.; Alahdab, F.; Alam, K.; Alam, T.; Alashi, A.; Alavian, S.M.; Alene, K.A.; Alijanzadeh, M.; Alizadeh-Navaei, R.; Aljunid, S.M.; Alkerwi, A.a.; Alla, F.; Allebeck, P.; Alouani, M.M.L.; Altirkawi, K.; Alvis-Guzman, N.; Amare, A.T.; Aminde, L.N.; Ammar, W.; Amoako, Y.A.; Anber, N.H.; Andrei, C.L.; Androudi, S.; Animut, M.D.; Anjomshoa, M.; Ansha, M.G.; Antonio, C.A.T.; Anwari, P.; Arabloo, J.; Arauz, A.; Aremu, O.; Ariani, F.; Armoon, B.; Ärnlöv, J.; Arora, A.; Artaman, A.; Aryal, K.K.; Asayesh, H.; Asghar, R.J.; Ataro, Z.; Atre, S.R.; Ausloos, M.; Avila-Burgos, L.; Avokpaho, E.F.G.A.; Awasthi, A.; Ayala Quintanilla, B.P.; Ayer, R.; Azzopardi, P.S.; Babazadeh, A.; Badali, H.; Badawi, A.; Bali, A.G.; Ballesteros, K.E.; Ballew, S.H.; Banach, M.; Banoub, J.A.M.; Banstola, A.; Barac, A.; Barboza, M.A.; Barker-Collo, S.L.; Bärnighausen, T.W.; Barrero, L.H.; Baune, B.T.; Bazargan-Hejazi, S.; Bedi, N.; Beghi, E.; Behzadifar, M.; Behzadifar, M.; Béjot, Y.; Belachew, A.B.; Belay, Y.A.; Bell, M.L.; Bello, A.K.; Bensenor, I.M.; Bernabe, E.; Bernstein, R.S.; Beuran, M.; Beyranvand, T.; Bhala, N.; Bhattarai, S.; Bhaumik, S.; Bhutta, Z.A.; Biadgo, B.; Bijani, A.; Bikbov, B.; Bilano, V.; Bililign, N.; Bin Sayeed, M.S.; Bisanzio, D.; Blacker, B.F.; Blyth, F.M.; Bou-Orm, I.R.; Boufous, S.; Bourne, R.; Brady, O.J.; Brainin, M.; Brant, L.C.; Brazinova, A.; Breitborde, N.J.K.; Brenner, H.; Briant, P.S.; Briggs, A.M.; Briko, A.N.; Britton, G.; Brugha, T.; Buchbinder, R.; Busse, R.; Butt, Z.A.; Cahuana-Hurtado, L.; Cano, J.; Cárdenas, R.; Carrero, J.J.; Carter, A.; Carvalho, F.; Castañeda-Orjuela, C.A.; Castillo Rivas, J.; Castro, F.; Catalá-López, F.; Cercy, K.M.; Cerin, E.; Chaiah, Y.; Chang, A.R.; Chang, H.-Y.; Chang, J.-C.; Charlson, F.J.; Chattopadhyay, A.; Chattu, V.K.; Chaturvedi, P.; Chiang, P.P.-C.; Chin, K.L.; Chitheer, A.; Choi, J.-Y.J.; Chowdhury, R.; Christensen, H.; Christopher, D.J.; Cicuttini, F.M.; Ciobanu, L.G.; Cirillo, M.; Claro, R.M.; Collado-Mateo, D.; Cooper, C.; Coresh, J.; Cortesi, P.A.; Cortinovis, M.; Costa, M.; Cousin, E.; Criqui, M.H.; Cromwell, E.A.; Cross, M.; Crump, J.A.; Dadi, A.F.; Dandona, L.; Dandona, R.; Dargan, P.I.; Daryani, A.; Das Gupta, R.; Das Neves, J.; Dasa, T.T.; Davey, G.; Davis, A.C.; Davitoiu, D.V.; De Courten, B.; De La Hoz, F.P.; De Leo, D.; De Neve, J.-W.; Degefa, M.G.; Degenhardt, L.; Deiparine, S.; Dellavalle, R.P.; Demoz, G.T.; Deribe, K.; Dervenis, N.; Des Jarlais, D.C.; Dessie, G.A.; Dey, S.; Dharmaratne, S.D.; Dinberu, M.T.; Dirac, M.A.; Djalalinia, S.; Doan, L.; Dokova, K.; Doku, D.T.; Dorsey, E.R.; Doyle, K.E.; Driscoll, T.R.; Dubey, M.; 
Dubljanin, E.; Duken, E.E.; Duncan, B.B.; Duraes, A.R.; Ebrahimi, H.; Ebrahimpour, S.; Echko, M.M.; Edvardsson, D.; Effiong, A.; Ehrlich, J.R.; El Bcheraoui, C.; El Sayed Zaki, M.; El-Khatib, Z.; Elkout, H.; Elyazar, I.R.F.; Enayati, A.; Endries, A.Y.; Er, B.; Erskine, H.E.; Eshrati, B.; Eskandarieh, S.; Esteghamati, A.; Esteghamati, S.; Fakhim, H.; Fallah Omrani, V.; Faramarzi, M.; Fareed, M.; Farhadi, F.; Farid, T.A.; Farinha, C.S.E.s.; Farioli, A.; Faro, A.; Farvid, M.S.; Farzadfar, F.; Feigin, V.L.; Fentahun, N.; Fereshtehnejad, S.-M.; Fernandes, E.; Fernandes, J.C.; Ferrari, A.J.; Feyissa, G.T.; Filip, I.; Fischer, F.; Fitzmaurice, C.; Foigt, N.A.; Foreman, K.J.; Fox, J.; Frank, T.D.; Fukumoto, T.; Fullman, N.; Fürst, T.; Furtado, J.M.; Futran, N.D.; Gall, S.; Ganji, M.; Gankpe, F.G.; Garcia-Basteiro, A.L.; Gardner, W.M.; Gebre, A.K.; Gebremedhin, A.T.; Gebremichael, T.G.; Gelano, T.F.; Geleijnse, J.M.; Genova-Maleras, R.; Geramo, Y.C.D.; Gething, P.W.; Gezae, K.E.; Ghadiri, K.; Ghasemi Falavarjani, K.; Ghasemi-Kasman, M.; Ghimire, M.; Ghosh, R.; Ghoshal, A.G.; Giampaoli, S.; Gill, P.S.; Gill, T.K.; Ginawi, I.A.; Giussani, G.; Gnedovskaya, E.V.; Goldberg, E.M.; Goli, S.; Gómez-Dantés, H.; Gona, P.N.; Gopalani, S.V.; Gorman, T.M.; Goulart, A.C.; Goulart, B.N.G.; Grada, A.; Grams, M.E.; Grosso, G.; Gugnani, H.C.; Guo, Y.; Gupta, P.C.; Gupta, R.; Gupta, R.; Gupta, T.; Gyawali, B.; Haagsma, J.A.; Hachinski, V.; Hafezi-Nejad, N.; Haghparast Bidgoli, H.; Hagos, T.B.; Hailu, G.B.; Haj-Mirzaian, A.; Haj-Mirzaian, A.; Hamadeh, R.R.; Hamidi, S.; Handal, A.J.; Hankey, G.J.; Hao, Y.; Harb, H.L.; Harikrishnan, S.; Haro, J.M.; Hasan, M.; Hassankhani, H.; Hassen, H.Y.; Havmoeller, R.; Hawley, C.N.; Hay, R.J.; Hay, S.I.; Hedayatizadeh-Omran, A.; Heibati, B.; Hendrie, D.; Henok, A.; Herteliu, C.; Heydarpour, S.; Hibstu, D.T.; Hoang, H.T.; Hoek, H.W.; Hoffman, H.J.; Hole, M.K.; Homaie Rad, E.; Hoogar, P.; Hosgood, H.D.; Hosseini, S.M.; Hosseinzadeh, M.; Hostiuc, M.; Hostiuc, S.; Hotez, P.J.; Hoy, D.G.; Hsairi, M.; Htet, A.S.; Hu, G.; Huang, J.J.; Huynh, C.K.; Iburg, K.M.; Ikeda, C.T.; Ileanu, B.; Ilesanmi, O.S.; Iqbal, U.; Irvani, S.S.N.; Irvine, C.M.S.; Islam, S.M.S.; Islami, F.; Jacobsen, K.H.; Jahangiry, L.; Jahanmehr, N.; Jain, S.K.; Jakovljevic, M.; Javanbakht, M.; Jayatilleke, A.U.; Jeemon, P.; Jha, R.P.; Jha, V.; Ji, J.S.; Johnson, C.O.; Jonas, J.B.; Jozwiak, J.J.; Jungari, S.B.; Jürisson, M.; Kabir, Z.; Kadel, R.; Kahsay, A.; Kalani, R.; Kanchan, T.; Karami, M.; Karami Matin, B.; Karch, A.; Karema, C.; Karimi, N.; Karimi, S.M.; Kasaeian, A.; Kassa, D.H.; Kassa, G.M.; Kassa, T.D.; Kassebaum, N.J.; Katikireddi, S.V.; Kawakami, N.; Karyani, A.K.; Keighobadi, M.M.; Keiyoro, P.N.; Kemmer, L.; Kemp, G.R.; Kengne, A.P.; Keren, A.; Khader, Y.S.; Khafaei, B.; Khafaie, M.A.; Khajavi, A.; Khalil, I.A.; Khan, E.A.; Khan, M.S.; Khan, M.A.; Khang, Y.-H.; Khazaei, M.; Khoja, A.T.; Khosravi, A.; Khosravi, M.H.; Kiadaliri, A.A.; Kiirithio, D.N.; Kim, C.-I.; Kim, D.; Kim, P.; Kim, Y.E.; Kim, Y.J.; Kimokoti, R.W.; Kinfu, Y.; Kisa, A.; Kissimova-Skarbek, K.; Kivimäki, M.; Knudsen, A.K.S.; Kocarnik, J.M.; Kochhar, S.; Kokubo, Y.; Kolola, T.; Kopec, J.A.; Kosen, S.; Kotsakis, G.A.; Koul, P.A.; Koyanagi, A.; Kravchenko, M.A.; Krishan, K.; Krohn, K.J.; Kuate Defo, B.; Kucuk Bicer, B.; Kumar, G.A.; Kumar, M.; Kyu, H.H.; Lad, D.P.; Lad, S.D.; Lafranconi, A.; Lalloo, R.; Lallukka, T.; Lami, F.H.; Lansingh, V.C.; Latifi, A.; Lau, K.M.-M.; Lazarus, J.V.; Leasher, J.L.; Ledesma, J.R.; Lee, P.H.; Leigh, J.; Leung, J.; Levi, M.; Lewycka, S.; Li, S.; Li, Y.; Liao, Y.; Liben, M.L.; Lim, L.-L.; Lim, S.S.; Liu, S.; Lodha, R.; Looker, K.J.; Lopez, A.D.; Lorkowski, S.; Lotufo, P.A.; Low, N.; Lozano, R.; Lucas, T.C.D.; Lucchesi, L.R.; Lunevicius, R.; Lyons, R.A.; Ma, S.; Macarayan, E.R.K.; Mackay, M.T.; Madotto, F.; Magdy Abd El Razek, H.; Magdy Abd El Razek, M.; Maghavani, D.P.; Mahotra, N.B.; Mai, H.T.; Majdan, M.; Majdzadeh, R.; Majeed, A.; Malekzadeh, R.; Malta, D.C.; Mamun, A.A.; Manda, A.-L.; Manguerra, H.; Manhertz, T.; Mansournia, M.A.; Mantovani, L.G.; Mapoma, C.C.; Maravilla, J.C.; Marcenes, W.; Marks, A.; MartinsMelo, F.R.; Martopullo, I.; März, W.; Marzan, M.B.; Mashamba-Thompson, T.P.; Massenburg, B.B.; Mathur, M.R.; Matsushita, K.; Maulik, P.K.; Mazidi, M.; McAlinden, C.; McGrath, J.J.; McKee, M.; Mehndiratta, M.M.; Mehrotra, R.; Mehta, K.M.; Mehta, V.; Mejia-Rodriguez, F.; Mekonen, T.; Melese, A.; Melku, M.; Meltzer, M.; Memiah, P.T.N.; Memish, Z.A.; Mendoza, W.; Mengistu, D.T.; Mengistu, G.; Mensah, G.A.; Mereta, S.T.; Meretoja, A.; Meretoja, T.J.; Mestrovic, T.; Mezerji, N.M.G.; Miazgowski, B.; Miazgowski, T.; Millear, A.I.; Miller, T.R.; Miltz, B.; Mini, G.K.; Mirarefin, M.; Mirrakhimov, E.M.; Misganaw, A.T.; Mitchell, P.B.; Mitiku, H.; Moazen, B.; Mohajer, B.; Mohammad, K.A.; Mohammadifard, N.; Mohammadnia-Afrouzi, M.; Mohammed, M.A.; Mohammed, S.; Mohebi, F.; Moitra, M.; Mokdad, A.H.; Molokhia, M.; Monasta, L.; Moodley, Y.; Moosazadeh, M.; Moradi, G.; Moradi-Lakeh, M.; Moradinazar, M.; Moraga, P.; Morawska, L.; Moreno Velásquez, I.; Morgado-Da-Costa, J.; Morrison, S.D.; Moschos, M.M.; Mountjoy-Venning, W.C.; Mousavi, S.M.; Mruts, K.B.; Muche, A.A.; Muchie, K.F.; Mueller, U.O.; Muhammed, O.S.; Mukhopadhyay, S.; Muller, K.; Mumford, J.E.; Murhekar, M.; Musa, J.; Musa, K.I.; Mustafa, G.; Nabhan, A.F.; Nagata, C.; Naghavi, M.; Naheed, A.; Nahvijou, A.; Naik, G.; Naik, N.; Najafi, F.; Naldi, L.; Nam, H.S.; Nangia, V.; Nansseu, J.R.; Nascimento, B.R.; Natarajan, G.; Neamati, N.; Negoi, I.; Negoi, R.I.; Neupane, S.; Newton, C.R.J.; Ngunjiri, J.W.; Nguyen, A.Q.; Nguyen, H.T.; Nguyen, H.L.T.; Nguyen, H.T.; Nguyen, L.H.; Nguyen, M.; Nguyen, N.B.; Nguyen, S.H.; Nichols, E.; Ningrum, D.N.A.; Nixon, M.R.; Nolutshungu, N.; Nomura, S.; Norheim, O.F.; Noroozi, M.; Norrving, B.; Noubiap, J.J.; Nouri, H.R.; Nourollahpour Shiadeh, M.; Nowroozi, M.R.; Nsoesie, E.O.; Nyasulu, P.S.; Odell, C.M.; OforiAsenso, R.; Ogbo, F.A.; Oh, I.-H.; Oladimeji, O.; Olagunju, A.T.; Olagunju, T.O.; Olivares, P.R.; Olsen, H.E.; Olusanya, B.O.; Ong, K.L.; Ong, S.K.; Oren, E.; Ortiz, A.; Ota, E.; Otstavnov, S.S.; Øverland, S.; Owolabi, M.O.; P A, M.; Pacella, R.; Pakpour, A.H.; Pana, A.; Panda-Jonas, S.; Parisi, A.; Park, E.-K.; Parry, C.D.H.; Patel, S.; Pati, S.; Patil, S.T.; Patle, A.; Patton, G.C.; Paturi, V.R.; Paulson, K.R.; Pearce, N.; Pereira, D.M.; Perico, N.; Pesudovs, K.; Pham, H.Q.; Phillips, M.R.; Pigott, D.M.; Pillay, J.D.; Piradov, M.A.; 
Pirsaheb, M.; Pishgar, F.; Plana-Ripoll, O.; Plass, D.; Polinder, S.; Popova, S.; Postma, M.J.; Pourshams, A.; Poustchi, H.; Prabhakaran, D.; Prakash, S.; Prakash, V.; Purcell, C.A.; Purwar, M.B.; Qorbani, M.; Quistberg, D.A.; Radfar, A.; Rafay, A.; Rafiei, A.; Rahim, F.; Rahimi, K.; Rahimi-Movaghar, A.; RahimiMovaghar, V.; Rahman, M.; Rahman, M.H.u.; Rahman, M.A.; Rahman, S.U.; Rai, R.K.; Rajati, F.; Ram, U.; Ranjan, P.; Ranta, A.; Rao, P.C.; Rawaf, D.L.; Rawaf, S.; Reddy, K.S.; Reiner, R.C.; Reinig, N.; Reitsma, M.B.; Remuzzi, G.; Renzaho, A.M.N.; Resnikoff, S.; Rezaei, S.; Rezai, M.S.; Ribeiro, A.L.P.; Roberts, N.L.S.; Robinson, S.R.; Roever, L.; Ronfani, L.; Roshandel, G.; Rostami, A.; Roth, G.A.; Roy, A.; Rubagotti, E.; Sachdev, P.S.; Sadat, N.; Saddik, B.; Sadeghi, E.; Saeedi Moghaddam, S.; Safari, H.; Safari, Y.; Safari-Faramani, R.; Safdarian, M.; Safi, S.; Safiri, S.; Sagar, R.; Sahebkar, A.; Sahraian, M.A.; Sajadi, H.S.; Salam, N.; Salama, J.S.; Salamati, P.; Saleem, K.; Saleem, Z.; Salimi, Y.; Salomon, J.A.; Salvi, S.S.; Salz, I.; Samy, A.M.; Sanabria, J.; Sang, Y.; Santomauro, D.F.; Santos, I.S.; Santos, J.V.; Santric Milicevic, M.M.; Sao Jose, B.P.; Sardana, M.; Sarker, A.R.; Sarrafzadegan, N.; Sartorius, B.; Sarvi, S.; Sathian, B.; Satpathy, M.; Sawant, A.R.; Sawhney, M.; Saxena, S.; Saylan, M.; Schaeffner, E.; Schmidt, M.I.; Schneider, I.J.C.; Schöttker, B.; Schwebel, D.C.; Schwendicke, F.; Scott, J.G.; Sekerija, M.; Sepanlou, S.G.; ServánMori, E.; Seyedmousavi, S.; Shabaninejad, H.; Shafieesabet, A.; Shahbazi, M.; Shaheen, A.A.; Shaikh, M.A.; Shams-Beyranvand, M.; Shamsi, M.; Shamsizadeh, M.; Sharafi, H.; Sharafi, K.; Sharif, M.; SharifAlhoseini, M.; Sharma, M.; Sharma, R.; She, J.; Sheikh, A.; Shi, P.; Shibuya, K.; Shigematsu, M.; Shiri, R.; Shirkoohi, R.; Shishani, K.; Shiue, I.; Shokraneh, F.; Shoman, H.; Shrime, M.G.; Si, S.; Siabani, S.; Siddiqi, T.J.; Sigfusdottir, I.D.; Sigurvinsdottir, R.; Silva, J.P.; Silveira, D.G.A.; Singam, N.S.V.; Singh, J.A.; Singh, N.P.; Singh, V.; Sinha, D.N.; Skiadaresi, E.; Slepak, E.L.N.; Sliwa, K.; Smith, D.L.; Smith, M.; Soares Filho, A.M.; Sobaih, B.H.; Sobhani, S.; Sobngwi, E.; Soneji, S.S.; Soofi, M.; Soosaraei, M.; Sorensen, R.J.D.; Soriano, J.B.; Soyiri, I.N.; Sposato, L.A.; Sreeramareddy, C.T.; Srinivasan, V.; Stanaway, J.D.; Stein, D.J.; Steiner, C.; Steiner, T.J.; Stokes, M.A.; Stovner, L.J.; Subart, M.L.; Sudaryanto, A.; Sufiyan, M.a.B.; Sunguya, B.F.; Sur, P.J.; Sutradhar, I.; Sykes, B.L.; Sylte, D.O.; Tabarés-Seisdedos, R.; Tadakamadla, S.K.; Tadesse, B.T.; Tandon, N.; Tassew, S.G.; Tavakkoli, M.; Taveira, N.; Taylor, H.R.; Tehrani-Banihashemi, A.; Tekalign, T.G.; Tekelemedhin, S.W.; Tekle, M.G.; Temesgen, H.; Temsah, M.-H.; Temsah, O.; Terkawi, A.S.; Teweldemedhin, M.; Thankappan, K.R.; Thomas, N.; Tilahun, B.; To, Q.G.; Tonelli, M.; ToporMadry, R.; Topouzis, F.; Torre, A.E.; Tortajada-Girbés, M.; Touvier, M.; Tovani-Palone, M.R.; Towbin, J.A.; Tran, B.X.; Tran, K.B.; Troeger, C.E.; Truelsen, T.C.; Tsilimbaris, M.K.; Tsoi, D.; Tudor Car, L.; Tuzcu, E.M.; Ukwaja, K.N.; Ullah, I.; Undurraga, E.A.; Unutzer, J.; Updike, R.L.; Usman, M.S.; Uthman, O.A.; Vaduganathan, M.; Vaezi, A.; Valdez, P.R.; Varughese, S.; Vasankari, T.J.; Venketasubramanian, N.; Villafaina, S.; Violante, F.S.; Vladimirov, S.K.; Vlassov, V.; Vollset, S.E.; Vosoughi, K.; Vujcic, I.S.; Wagnew, F.S.; Waheed, Y.; Waller, S.G.; Wang, Y.; Wang, Y.-P.; Weiderpass, E.; Weintraub, R.G.; Weiss, D.J.; Weldegebreal, F.; Weldegwergs, K.G.; Werdecker, A.; West, T.E.; Whiteford, H.A.; Widecka, J.; Wijeratne, T.; Wilner, L.B.; Wilson, S.; Winkler, A.S.; Wiyeh, A.B.; Wiysonge, C.S.; Wolfe, C.D.A.; Woolf, A.D.; Wu, S.; Wu, Y.-C.; Wyper, G.M.A.; Xavier, D.; Xu, G.; Yadgir, S.; Yadollahpour, A.; Yahyazadeh Jabbari, S.H.; Yamada, T.; Yan, L.L.; Yano, Y.; Yaseri, M.; Yasin, Y.J.; Yeshaneh, A.; Yimer, E.M.; Yip, P.; Yisma, E.; Yonemoto, N.; Yoon, S.-J.; Yotebieng, M.; Younis, M.Z.; Yousefifard, M.; Yu, C.; Zadnik, V.; Zaidi, Z.; Zaman, S.B.; Zamani, M.; Zare, Z.; Zeleke, A.J.; Zenebe, Z.M.; Zhang, K.; Zhao, Z.; Zhou, M.; Zodpey, S.; Zucker, I.; Vos, T.; Murray, C.J.L. Global, regional, and national incidence, prevalence, and years lived with disability for 354 diseases and injuries for 195 countries and territories, 1990-2017: a systematic analysis for the Global Burden of Disease Study 2017. The Lancet 2018, 392, 1789-1858, https://doi.org/10.1016/S0140-6736(18)32279-7.

44. Lai, L.; Fonzo, O.; Tykot, R.H.; Goddard, E.; Hollander, D. Le due comunita di Scaba'e Arriu (Siddi): Risorse alimentari nella Sardegna del III millennio a.C. indagate tramite analisi isotopiche di tessuti ossei. Studio antropologico dei reperti umani. In: Proceedings of the XLIII Riunione Scientifica dell'Istituto Italiano di Preistoria e Protostoria: l'Età del Rame in Italia. Bologna, Italy, 26-29 November 2008, 2011; pp. 401-408.

45. So1tysiak, A. Cereal grinding technology in ancient Mesopotamia: evidence from dental microwear. J. Archaeol. Sci. 2011, 38, 2805-2810, https://doi.org/10.1016/j.jas.2011.06.025.

46. Schultz, M.; Carli-Thiele, P.; Schmidt-Schultzf, T.H.; Kierdorf, U.; Kierdorf, H.; Teegen, W.R.; Kreutz, K. Enamel Hypoplasias in Archaeological Skeletal Remains. In: Dental Anthropology. Alt, K.W.; Rösing, F.W.; Teschler-Nicola, M. Eds, Springer, Vienna, 1998; pp. 293-311, https://doi.org/10.1007/978-3-70917496-8_16.

47. Murgia, M.E.; Murgia, M.S.; Casula, E.; Casu, C.; Fonzo, O.; Garau, A.; Paglietti, G.; Orrù, G. Dental pathology in present-day and copper age samples. In: J. Osteointegrat., Proceedings of the XXVII Congresso Nazionale del Collegio dei Docenti Universitari in Discipline Odontostomatologiche. Milan, Italy, 10-12 September 2020; Ariesdue: Milan, Italy, Volume 12, 2020; pp. 613. 